\title{
ALGUNS RITMOS NOS ORÁCULOS DE RUI PIRES CABRAL
}

\author{
Julia Telésforo Osório ${ }^{1}$
}

\begin{abstract}
RESUMO: Neste artigo, apresento a leitura de quatro poemas pertencentes ao livro Oráculos de Cabeceira (2009), do poeta português contemporâneo Rui Pires Cabral, a fim de ler ritmos poéticos que dialoguem com as características do tempo contemporâneo. Para tanto, refleti acerca da necessidade de adotar uma postura teórica diferente da clássica de análise literária, representada pelas tradicionais teorias de versificação.
\end{abstract}

PALAVRAS-CHAVE: Rui Pires Cabral; Oráculos de Cabeceira; Ritmo; Contemporaneidade; Poesia Portuguesa.

\section{SOME RHYTHMS OF RUI PIRES CABRAL'S ORACLES}

\begin{abstract}
In this paper, I present a reading of four poems in the book Oráculos de Cabeceira (2009), written by the portuguese contemporary poet Rui Pires Cabral, in order to read poetic rhythms that communicate with the characteristics of the contemporary time. Therefore, I reflected about the need to adopt a different theoretical analysis face to the literary classic represented by traditional theories of versification.
\end{abstract}

KEYWORDS: Rui Pires Cabral; Oráculos de Cabeceira; Rhythm; Contemporary; Portuguese Poetry. ${ }^{1}$ Mestranda em Teoria Literária pelo Programa de Pós-graduação em Literatura da Universidade Federal de
Santa Catarina (UFSC). E-mail: juliaosorio@gmail.com. 
Estou farto do lirismo que pára e vai averiguar no dicionário o cunbo vernáculo de um vocábulo. Abaixo os puristas

Todas as palavras sobretudo os barbarismos universais Todas as construções sobretudo as sintaxes de exceção Todos os ritmos sobretudo os inumeráveis ("Poética", de Manuel Bandeira).

\section{Introdução}

Das questões de linguagem poética, o ritmo talvez encene papel de protagonista, pois vários são os autores que o conceituam a fim de estruturar seus trabalhos críticoteóricos. Na dificuldade de uma definição una, o que se têm diante dos olhos são multiplicidades conceituais sem haver uma verdade a ser decifrada, definida e aplicada universalmente, como é possível com o estudo dos componentes químicos da água (Cf. MOISÉS, 2003). Em mim, o que fica disso é uma interrogação: possuiria cada poeta, leitor, crítico ou teórico o seu ritmo? Acredito que esse questionamento seja uma materialidade do que talvez seja a própria literatura: arte que mobiliza, esteticamente, as possibilidades de significação a partir do constante jogo entre autor e leitor pela linguagem verbal. Assim, para cada um, independente do papel encenado diante do texto literário, o ritmo em poesia possa ser entendido como conceito e não como definição, construído no jogo das possibilidades.

Neste artigo, apresento algumas considerações sobre essa "pedra fundamental" dos estudos poéticos a partir da leitura de quatro poemas do livro Oráculos de cabeceira (2009), do poeta português contemporâneo Rui Pires Cabral. Meu desejo principal consiste em refletir acerca de quais seriam os elementos rítmicos mobilizados em tal poesia, cujos versos apresentam-se sob a forma "livre". Um movimento intelectual já percorrido por outros autores e estudiosos, mas que acredito ainda ser produtivo no trato com as obras contemporâneas, em especial àquelas de pouca ou quase nenhuma visibilidade como é o caso desse livro, questão já concretizada pelo próprio poeta em breve dedicatória dos Oráculos: "para os meus trezentos leitores" (CABRAL, 2009).

\section{Rui Pires Cabral e a novíssima literatura portuguesa}

Poeta e tradutor de língua inglesa ${ }^{2}$, Rui Pires Cabral nasceu no noroeste de Portugal, em Macedo de Cavaleiros, em 1967. Tal autor já publicou doze livros de poesia,

\footnotetext{
2 De seus inúmeros trabalhos de tradução, destacam-se àqueles com os livros Uma Casa no Fim do Mundo, Sangue do Meu Sangue e Dias Exemplares de Michael Cunningham.
} 
sendo a maioria por editoras e alguns, sobretudo os primeiros, editados por ele próprio ${ }^{3}$. Sua obra é envolvida por um suposto desconhecimento que creio ser consequente do pouco contato nosso (público brasileiro) com seus os versos, situação essa que talvez esteja relacionada ao fato de que o número de impressão dos exemplares de seus livros ser baixo ${ }^{4}$ por parte das editoras portuguesas que publicaram livro do autor, dentre elas a Averno, que imprime títulos em tiragens únicas.

Contudo, é reconhecível, entre os estudiosos dedicados à poesia portuguesa, que o nome de Rui Pires Cabral tornou-se uma das referências para o entendimento da recente cena literária do além-mar. Em Portugal, há pelo menos duas décadas, da última do século passado à primeira deste século, um expressivo número de autores vem publicando livros de poesia, e estudos recentes tem tematizado em livros, artigos e antologias esta "novíssima literatura portuguesa".

A intelectual portuguesa Rosa Maria Martelo publicou, em 1999, um artigo de viés panorâmico, nomeado "Anos noventa: Breve roteiro da novíssima poesia portuguesa". Nele, seu olhar crítico é direcionado à seleção de vozes representativas no final do "século de ouro da poesia portuguesa" e formado por ponderações acerca das tendências poéticas daquele país no final do século XX e menção a nomes de poetas que publicaram a partir da década de 1990. Ela também expos, nesse texto, notas críticas sobre tais produções literárias - registro nominativo de autores como Ana Luísa Amaral, Fernando Pinto do Amaral, Luis Quintais, Rui Pires Cabral e outros (1999, p. 233-235) que, hoje, já são (re)conhecidos pela crítica literária. Em meio a um cenário de pluralidades de nomes, temas, obras e estilos, Martelo atentou para o que poderiam ser os elementos componentes do fio condutor daquele momento literário português:

[...] a memória pessoal e literária, a valorização da experiência subjectiva, a exploração do fragmento narrativo subitamente revelador, a contraposição do poder criativo da linguagem a uma experiência existencial ou ontológica de perda, de desencontro e de ruína, o recuo pelo humor e pela ironia são elementos que parecem essenciais para caracterizar globalmente a poesia portuguesa mais recente (MARTELO, 1999, p. 233).

\footnotetext{
${ }^{3}$ São estes os livros publicados por Rui Pires Cabral: Pensão Bellinæona e Outros Poemas (Edição de Autor, 1994), Geografia das Estações (Edição de Autor, 1994), A Super-Realidade (Edição de Autor, 1995), Música antológica \& Onze Cidades (Presença, 1997), Praças e Quintais (Averno, 2003), Longe da Aldeia (Averno, 2005), Capitais da Solidão (Teatro Vila Real, 2006), Oráculos de Cabeceira (Averno 2009), A pocket guide to birds (Edição de Autor, 2009), A Super-Realidade (Língua Morta, 2011), Biblioteca dos Rapazes (Pianola, 2012) e Broken (Paralelo W, 2013).

${ }^{4}$ Em números, cito as tiragens de 500 exemplares de Capitais da Solidão, 350 de Praças e Quintais, 350 de Longe da Aldeia e 300 de Oráculos de cabeceira.
} 
Oito anos se passaram e em outro trabalho crítico, nomeado Vidro do mesmo vidro (2007), Martelo abordou a poesia portuguesa mais recente com maior amplitude históricoreflexiva ao deslocar seu olhar desde o ano de 1961. Segundo ela, podem as manifestações poéticas datadas em um tempo recente
permanecer textualista[s] (ao ser[em] erudita[s], recorrendo a uma intertextualidade explícita e promovendo no leitor o prazer do reconhecimento); mas, simultaneamente, ela[s] pode[m] centrar-se em pequenos acontecimentos quotidianos banais, sem grandeza aparente, procurando situar a poesia como uma epifania na vida [...] Hoje, a poesia portuguesa mantém-se frequentemente em diálogo com a tradição poética e artística (através da citação, da reformulação ou da ekphrasis) muitas vezes associando esse diálogo a um processo de evocação que se combina com um efeito de realismo e um registro lírico [...] (MARTELO, 2007, p. 47-48, Grifos da autora).

A respeito da obra de Rui Pires Cabral, Martelo pontuou que sua poesia "torna-se narrativa através da exploração das pequenas histórias da vida comum e no registro de uma experiência urbana de desumanização" (2007, p. 49). De Música Antológica \& Onz̧e Cidades a Oráculos de Cabeceira, as experiências de leitura configurar-se-iam em pequenas epifanias (p. 47) de um sujeito poético em trânsito, transformadas em matéria poética que narra a contemporaneidade através da mobilização de signos referentes à concretude de espaços e situações urbanas, como se pode ler no poema "Trinity Sunday", pertencente a outro livro de Rui Pires Cabral, intitulado Longe da Aldeia (Averno, 2005):

$$
\begin{aligned}
& \text { Inadvertido, reconheces } \\
& \text { o fio que te prende } \\
& \text { a este ponto do tempo } \\
& \text { e da paisagem } \\
& \text { Na torre de St Mary's, } \\
& \text { em Warwick, } \\
& \text { de onde se avistam } \\
& \text { seis condados. } \\
& \text { E assim chegas completo } \\
& \text { à tua canção, forasteiro. } \\
& \text { Sem nome, sem história } \\
& \text { (CABRAL, 2005. p. 26). }
\end{aligned}
$$

Nesse deslocamento, pode-se observar o diálogo entre o sujeito poético e a noção de flânerie, desenvolvida por Charles Baudelaire, cuja obra, tanto crítico-teórica quanto 
literária, norteou muitos dos caminhos trilhados pela poesia dos séculos XIX e $\mathrm{XX}^{5}$. Paul Valéry considera o poeta francês como um clássico, pois "clássico é o escritor que traz um crítico em si mesmo, associando-o intimamente a seus trabalhos" (VALÉRY, 1999, p. 25). Tanto Baudelaire, quanto Rui Pires Cabral, lá e aqui, antes e agora, transparece(ra)m a singular relação com o seu tempo em seus livros, que materializam um constante movimento de olhar a cidade, suas cenas e contradições tal qual um flanêur atento às minuciosidades de cada passo e de cada acontecimento. Os sujeitos poéticos desses dois poetas, seja no século XIX ou no início do século XXI, fizeram poemas com o que houvesse de poético ao seu redor, gesto esse que problematiza, literariamente, o próprio ato descritivo, que caracteriza a obra de Rui Pires Cabral, ao passo que nela há um olhar o espaço urbano e somente as descrições, o testemunho da pressa e da urgência que singularizam o tempo contemporâneo.

Nessa poesia, muitas vezes o sujeito poético parece interromper seu passo em meio à profusão e a velocidade características do tempo contemporâneo, deparando-se com situações rotineiras num impulso de ler o mundo para além de Lisboa, por um universal cotidiano comum aos mais diversos lugares. Tal interlocução, acompanhada da "narrativa da contemporaneidade", construída a partir do uso de temáticas "partilháveis ao leitor" (Cf. MARTELO, 2007. p. 46), não restringe, no entanto, sua poética a uma simples exposição de travessias urbanas, pois, guardadas as devidas proporções, a analogia do autor de $V$ ariedades (VALÉRY, 1999) torna-se interessante para refletir, criticamente, os poemas de Rui Pires Cabral, em cuja obra o leitor se depara com um questionamento tensionado, sobretudo, pelas formas rítmicas.

\section{Questões de tradição}

Tornou-se excessivo, ao longo da história da literatura, o gesto de abordar, analiticamente, o poema na busca da identificação, em sua estrutura, de enunciados pertencentes às teorias versificatórias - modelos de composição formulados a partir da leitura de textos canônicos cujos autores e seus respectivos procedimentos artísticos, como Luís de Camões e os seus Os Lusíadas, por exemplo, já foram consagrados e legitimados pelos estudiosos dedicados à Literatura.

\footnotetext{
${ }^{5}$ Aqui me refiro à crítica acerca da obra de Constantin Guys presente em O Pintor da Vida Moderna, em que Charles Baudelaire retratou a modernidade como "o transitório, o efêmero, o contingente", e formulou o conceito de flâneur como homem do mundo que, ao deambular no espaço das grandes cidades do século XIX, apaixona-se pela multidão e deseja-a (BAUDELAIRE, 1996, p. 21 e 26).
} 
Devido a isso, o (re)conhecimento da tradição clássica da teoria do verso continua a ser fundamental para aquele que se propõe a estudar poesia, já que ela norteou uma postura crítica que visou, e ainda visa em muitos contextos críticos, analisar e legitimar o valor positivo da linguagem poética e, consequentemente, da obra de determinado autor. A partir do século XIX, no entanto, o status dessa tradição como sendo a maneira "correta", "legítima" e "única possível" para ler, analisar e também compor uma linguagem poética foi, veementemente, questionado por intelectuais que não reconheciam mais a possibilidade de instaurar um "estado de poesia" (VALÉRY, 1999, p. 200) nas obras vinculadas ao sistema compositório clássico de metrificação. No que se denominou com "Simbolismo", o verso livre configurou-se como um recurso formal contrário à clássica postura de autores que preferiam utilizar as receitas métricas para compor seus versos. Sobre tal questão, afirmou Paul Valéry:

Uma das maiores disputas da época foi, como se sabe, a disputa interna do Verso Livre. [...] A legitimidade, a oportunidade ou a necessidade de se desfazer das regras tradicionais; as demonstrações do a favor e do contra; a prova do a favor e do contra através da teoria, do fato, da fonética, da história... [...] Mas alguns anos depois de 1870, ou seja, no momento em que o Parnaso, no apogeu de sua glória, através da reação ao Romantismo, ultrapassou as próprias condições dos poetas clássicos, pronuncia-se um movimento insurrecional, cujos primeiros estremecimentos se encontraram em algumas páginas de Rimbaud e no comportamento muito pouco parnasiano dos poemas de Verlaine que sucedem a seus Poèmes Saturniens. Sua graça livre nos opõe à aparência escultural e às sonoridades sólidas dos versos feitos pelos discípulos de Leconte de Lisle. Eles introduzem uma forma simples e cantante inspirada, algumas vezes, na poesia popular (p. 73-74, Grifos do autor).

Tal conjuntura, instaurada, por exemplo, nas obras de poetas como Arthur Rimbaud, Paul Verlaine, Stéphane Mallarmé, Victor Hugo e outros está relacionada ao fato de que "cada poema [cria] um novo ritmo" (GOLDSTEIN, 2008. p. 18); ritmo esse que poderia ser decorrente das "normas métricas", pois se escolheria obedecê-las caso elas fossem proveitosas para alcançar os efeitos poéticos desejados. Valéry metaforizou essa situação através da imagem de um “jovem” que almejava todas as formas e não encontrava satisfação nos procedimentos formais de seu tempo. Segundo o autor francês:

[...] Ele [o jovem] tende a rejeitar indistintamente tudo o que se funde em uma tradição ou em textos, como repele o que se baseia em uma argumentação e em uma dialética mais ou menos rigorosa; como considera eternamente provisória e sempre prematura qualquer afirmação que se apóie no conhecimento científico, física ou geologia, ou biologia, e que explore os resultados além de qualquer verificação. Confronta todas essas doutrinas; vê em cada uma apenas a força dos argumentos que ela opõe a todos os outros. A soma lhe parece igual a 
zero. O que lhe sobra? Por onde fugir dessa nada intelectual e da importância que dele resulta? Resta-lhe ser ele mesmo, ser jovem e, principalmente, estar resolvido a só admitir aquilo do qual sinta uma necessidade interior real, a existência esperada por seu ser mais profundo; a não admitir o que se transforma em palavras cujo significado não seja uma experiência imediata e um valor representado no tesouro de suas afeições. Ídolos por ídolos, prefere aqueles feitos apenas de sua substância aos que são propostos por outros. Interroga-se. Encontra. Constata que só lhe resta uma certeza: a emoção imposta por certos aspectos da natureza e da vida, e por certas obras do homem [...] (VALÉRY, 1999, p. 71, Grifos do autor).

Resistente aos modelos de composição poética tradicionalmente legitimados, alguns poetas do século XIX questionaram os enunciados versificatórios em suas obras. Como dito, outros autores vinculados à tradição métrica também destacaram a dificuldade em conceituar o "ritmo" em poesia; dentre eles, Amorim de Carvalho, intelectual português, que afirmou que "sobre o problema do ritmo escreveram-se inúmeros ensaios e livros, chegando as mais diferentes conclusões" (CARVALHO, 1987). Ao reconhecer as divergências conceituais entre muitos estudiosos, o autor de Teoria geral da versificação (1987) evidenciou seu conceito de ritmo, relacionando-o às sílabas do verso ao sistematizar modelos e receitas métricas ideias para a composição poética:

O ritmo é um esquema sonoro regular, musicalmente mais ou menos regular agradável preenchível por um certo número de "sílabas" que compõe a palavra ou palavras do verso. [...] Nos versos perfeitos, modulares, a ideia solidariza-se de tal modo com o ritmo, que à terminação de cada verso corresponde a uma pausa lógica, embora o pensamento se desenvolva e se complete no verso ou versos seguintes, como sucede quase sempre. Quando as duas pausas, de ritmo e de ideia, não coexistem no fim de um verso, não se percebendo a separação musical e lógica entre esse verso e o imediato, a terminação do primeiro é apenas gráfica e convencional. (p. 18 e 23)

Rogério Chociay, intelectual brasileiro que também compôs uma teoria do verso (1974), questionou, em sua obra, o papel da métrica como a única via possível para o estudo do poema. De acordo com ele:

$\mathrm{O}$ andamento, nos versos, e a cadência, nas estrofes, constituem a parcela mais rigorosamente mensurável da versificação, podendo ser indicados por meio de esquemas ou metros. Sendo apenas um aspecto dentro da teoria geral do poema, o aprendizado da Métrica não implica o da poesia, mas tão somente a assimilação de um sistema segundo o qual a poesia tem-se realizado tradicionalmente. Assim entendido, o metro não surge como finalidade, senão como apoio, base em função da qual a poesia pode ou pôde corporificar-se. A organização métrica funciona, portanto, como convenção, como um primeiro (não o mais importante, nem o mais necessário) indício de que o que se tem sob os olhos, na leitura, ou 
nos penetra os ouvidos, na declamação, deva ser poesia e não outra coisa (CHOCIAY, 1974, p. 2, Grifos do autor).

Tal é a complexidade em sistematizar o ritmo de maneira definitiva que Chociay, mesmo com o intuito de expor os clássicos preceitos da teoria do verso ${ }^{6}$, não limitou as possibilidades de composição poética às teorias tradicionais e, assim, conceituou ritmo:

[...] ritmo é justamente a resultante percebida da solidariedade desses níveis da linguagem que encorpam o poema; profundamente arraigado à expressão, não surge devido a um aprendizado de preceitos, mas ao próprio dinamismo criador e verbalizador do artista. É, antes de tudo, percebido, sentido, e não como efeitos parciais ou colaterais, mas como uma resultante global. Podem-se indicar pistas, elucidar detalhes, apontar aspectos para melhor apreciá-lo, mas, ao fim, dele restará sempre um quantum tão imensurável como a própria expressão poética a que se irmana. O metro representa apenas a abstração de um dos apoios rítmicos do poema [...] (p. 2, grifos do autor).

Se o ritmo pode ser (re)conhecido de inúmeras maneiras, sendo inviável pretender uma única via de análise que seja suficiente para ler determinado poema, identificarei, ao longo deste artigo, elementos que sejam constitutivos da linguagem poética de Rui Pires Cabral, que evidenciem a ideia de "ritmo em geral", conceituada por Augustín García Calvo como sendo:

[...] toda sucessão mais ou menos marcada ou descuidada, mais ou menos variada ou constante, mais ou menos cortante ou ondulatória [...] a esse ritmo opõe-se essa outra maneira de ritmo que dizemos aritmética, a qual quer dizer aquela cuja descontinuidade, alternância de momentos diferentes e retornos periódicos de um mesmo, produzem, além disso, por virtude do próprio cômputo que isso implica, tramos "de tempo". (intervalos entre cada sucessivo retorno do mesmo e inclusive durações de produção desse 'o mesmo'), que são entre si exatamente iguais em medida [e] dão uma ilusão suficientemente real de serem iguais (CALVO, 2006. p. 104 e 105). ${ }^{7}$

Mais do que buscar a definição de ritmo na poesia do autor de Música Antológica \& Onze Cidades (Presença, 1997), apresento leituras possíveis, desvinculadas de uma postura de análise que vise somente identificar ou não a presença, no texto poético, de receitas métricas, enunciadas nos tratados de versificação. É meu objetivo, portanto, não definir,

\footnotetext{
${ }^{6}$ Rogério Chociay compôs sua Teoria do Verso a partir da releitura de outros tratados de versificação, por exemplo, a obra de Amorim de Carvalho, citada neste artigo.

7 Trecho original: Ritmo em general pués [...], toda sucesión lo tiene, más o menos marcado o descuidado, más o menos variado o costante, más o menos cortante u ondulatório, pero siempre 'más o menos': a este ritmo se opone esa otra manera de ritmo que décimos aritmética, lo cual quiere decir aquél cuya discontinuidad, alternância de momentos diferentes y retornos Periódicos de uno mismo, producen además, por virtud del proprio cómputo que ello implica, tramos "de tiempo" (intervalos entre cada sucesivo retorno de lo mismo y aun duraciones de producción de ese 'lo mismo') que son entre si esactamente iguales em medida o - lo que da lo mismo para el caso- dan una ilusión suficientemente real de ser iguales. Tradução de Roberto Webber Anflor.
} 
mas conceituar o ritmo poético construído por Rui Pires Cabral, materializado, sobretudo, pelo uso frequente de determinadas células rítmicas e que, nesse sentido, potencializam uma multiplicidade de leituras possíveis dessa obra, que possui pouco mais de quinze anos de existência.

\section{3. “Oráculos", pra que te quero?}

Oráculos de Cabeceira (2009) possui uma curiosa estrutura editorial, pois apresenta vinte e sete poemas, cujos títulos constituem-se por frases, acompanhadas de notas de rodapé remetentes uma lista constituída por nomes de obras, apresentada no final do livro tal qual modelos de citação e de referência de textos acadêmicos (Cf. MAFFEI, 2011): uma pequena "bibliografia" construída por autores como Fiódor Dostoievski, Italo Calvino, Camilo Castelo Branco, Jorge Luis Borges, Edgar Allan Poe, etc.

Tais poemas registram impressões de um sujeito poético ${ }^{8}$ que parece transitar pelas complexas geografias contemporâneas, reiteradas alusões às situações ocorridas em Portugal, cuja capital é referenciada nominalmente (CABRAL, 2009, p. 20), e também na Inglaterra, através da referência às cidades de Warwickshire, acompanhada pelo relato de seus bosques (p. 32) e de Londres, embora seja a capital inglesa mencionada através do uso de termos espaciais como "Shepherd's bush" (p. 13) e de "descrições" dos parques públicos (p. 16). Mais do que a vontade de expor as rotinas urbanas através do constante uso de signos referentes ao tempo presente, nota-se um sentimento de desassossego por parte daquele que questiona, poeticamente, o espaço em que vive ao narrá-lo de maneira "prosaica", ao passo que não há, nos poemas, o desenvolvimento de temáticas complexas, de acordo com Rosa Maria Martelo (2007). Entretanto, se esses "prosaísmos" fossem descomprometidos e houvesse a falta de uma consciência artística na elaboração de tal obra, que papel teria a forte presença das notas de rodapé que marcam todos os títulos dos Oráculos de Cabeceira? De que serviria uma listagem vasta, composta por nomes cruciais para a formação de um cânone literário? Qual seria, enfim, a função do uso desse recurso textual? Acredito que isso seja um indício da consciência da tradição literária do autor que

\footnotetext{
8 Para pensar na importância do sujeito poético dos poemas desse livro, optei por trabalhar com a hipótese de ser ele um indivíduo que joga com a alteridade, mas esse "outro" que o acompanha pode não compartilhar, necessariamente, com as suas opiniões. Poderia, então, tal uso configurar-se num recurso retórico, pois, mesmo quando há a presença da segunda pessoa do plural nos termos verbais e nominais, acredito que a carga semântica do enunciado de um determinado poema centra-se num indivíduo e não em dois ou mais, já que as temáticas dos poemas estão relacionadas entre si, como se, de fato, Oráculos de cabeceira, formasse, em sua totalidade, um "poema-narrativo".
} 
desejou materializar tal questão na estrutura do próprio livro, cujo título aludiria à ideia dos "oráculos" como uma espécie de bibliografia, formada por livros consultados “miticamente" pelo poeta.

Poderia, assim, o leitor compreender esse gesto de citar como uma tentativa de estabelecer a interlocução entre os conteúdos textuais referenciados aos temas lidos em cada poema? Não creio que essa hipótese seja suficiente para entender um ato tão singular, pois os cânones mencionados poderiam não influenciar, obrigatoriamente, a leitura temática, já que a listagem encontra-se no final do livro. E o leitor poderia encarar este fragmento como uma simples frase, "Não tenhas confiança na tua juventude" (CABRAL, 2009, p. 31), sem saber que ela se encontra no livro $A$ voz subterrânea de Dostoievski, retirada da página número 108 da edição traduzida por Célia Henriques e Vitor Silva Tavares, publicada pela editora lisboeta "\&etc" em 1989, conforme a "referência bibliográfica" transcrita nas últimas páginas dos Oráculos de cabeceira. Se, ao contrário disso, o leitor já conhecesse todas essas referências bibliográficas antes de deparar-se com os poemas de Rui Pires Cabral e, assim, encontrasse similaridades temáticas entre os textos, essa poderia ser, sim, uma das possíveis justificativas para tentar compreender o papel das citações. Acredito, porém, que tal atitude materializa a consciência do autor de um cânone literário, recordado no momento de composição de cada poema que registra, mnemonicamente, parte de uma outra obra como Coração, Cabeça e Estômago de Camilo Castelo Branco presente no título do poema localizado na página 38 do referido livro. Eis a reprodução de uma das imagens dessa "bibliografia": 


\section{ABERTOS AO ACASO:}

\footnotetext{
1 FrIGYES KARINTHY, A Journey Round My Skull [tradução inglesa de Vernon Duckworth Barker], Corvina, Budapeste, 1992, p. 52.

2 A. J. A. Symons, The Quest for Corvo, The New York Review of Books, Nova Iorque, 2001, p. 87.

3 IRIS Murdoch, O Mar, o Mar [tradução de José Miguel Silva], Relógio D’Água, Lisboa, 2005, p. 212.

4 Agustina Bessa-Luis, Conversaçōes com Dmitrie e Outras Fantasias, $\mathrm{Na}$ Regra do Jogo, Lisboa, 1981, p. 11.

5 BRUNo Schulz, Tratado dos Manequins ou O Segundo Génesis [tradução de Aníbal Fernandes], \&etc, Lisboa, 1983, p. 17.

6 Evelyn Waugh, A Little Learning, Sidgwick \& Jackson, Londres, 1973, p. 189.

7 JAMES GAVIN, Deep in a Dream: The Long Night of Chet Baker, Vintage, Londres, 2003, p. 329.

8 Charles Dickens, The Christmas Books, Cassell \& Company, Londres, Nova Iorque, Toronto e Melbourne, 1910, p. 136.

9 CESARE PAVESE, A Lua e as Fogueiras [tradução de Manuel de Seabra], Arcádia, Lisboa, s/d, p. 126.

10 Derek Jarman, Modern Nature, Vintage, Londres, 1992, p. 138.

11 WillaAm Beckford, Diário de William Beckford em Portugal e Espanha [tradução de João Gaspar Simões], Biblioteca Nacional, Lisboa, 1988 , p. 123.

12 João Miguel Fernandes Jorge, Um Quarto Cheio de Espelhos, Quetzal, Lisboa, 1987, p. 61.

${ }^{13}$ Henry James, The Europeans, Penguin, Harmondsworth, 1985, p. 54.

14 Albert Camus, A Morte Feliz [tradução de José Carlos González], Livros do Brasil, Lisboa, s/d, p. 102.

15 Christopher Isherwood, Lions and Shadows, Minerva, Londres, 1996, p. 148.
}

Imagem 1: Uma das páginas que constituem as "referências bibliográficas" dos Oráculos de cabeceira".

É possível, portanto, observar a consciência da existência e da força do cânone literário por Rui Pires Cabral. E, nesse sentido, a escolha e respectiva adoção, em sua obra, do verso livre não seria algo arbitrário, pois isso poderia representar uma espécie de questionamento, visto que o uso de notas de rodapé e de outros recursos formais estabeleceria o diálogo com a tradição literária de forma singular, já que criaria uma ideia de ritmo diferente daquela clássica, apresentada em muitos tratados de versificação ao longo da história da literatura.

\footnotetext{
${ }^{9}$ A reprodução dessa imagem foi autorizada por Rui Pires Cabral.
} 


\section{Possibilidades rítmicas em quatro atos}

Apresento, neste primeiro “ato", uma leitura do primeiro poema dos Oráculos de cabeceira, nomeado "I felt that it was all unreal" (CABRAL, 2009, p. 11) ${ }^{10}$, que traduzo, livremente, por "Senti que isso tudo era irreal". Nele, o sujeito poético narra, em um suposto tempo presente, o movimento das "miniaturas" ao anoitecer, quando elas atravessam a cidade no retorno aos seus lares ${ }^{11}$ :

Chega ao fim do dia a hora mais lenta, quando o céu é vago e as luzes se acendem no prédio da frente.

Vemo-los por vezes dentro das janelas, vultos delicados como miniaturas ou meros reflexos que passam nos vidros.

Alguns prosseguem encargos de sombra, outros detêm-se a olhar a rua, no gesto a expressão do seu puro enigma.

E são como provas de coisa nenhuma. Se acaso nos fitam, parecem dizer: a morte não será decerto mais estranha que a vida.
Chega ao fim do dia

a hora mais lenta, quando o CÉU

é vago e as luzes se aCENdem no prédio da FRENte.

Vemo-los por VEzes dentro das janelas, VULtos delicados como miniaTUras ou meros reflexos que PAssam nos VIdros.

Alguns prosseguem encargos de sombra, outros deTÊM-se a olhar a rua, no GESto a expressão do seu Puro eNIGma.

E são como PROvas de coisa nenhuma. Se aCAso nos fitam, parecem DIzer: a morte não será deCERto mais estranha que a VIda.

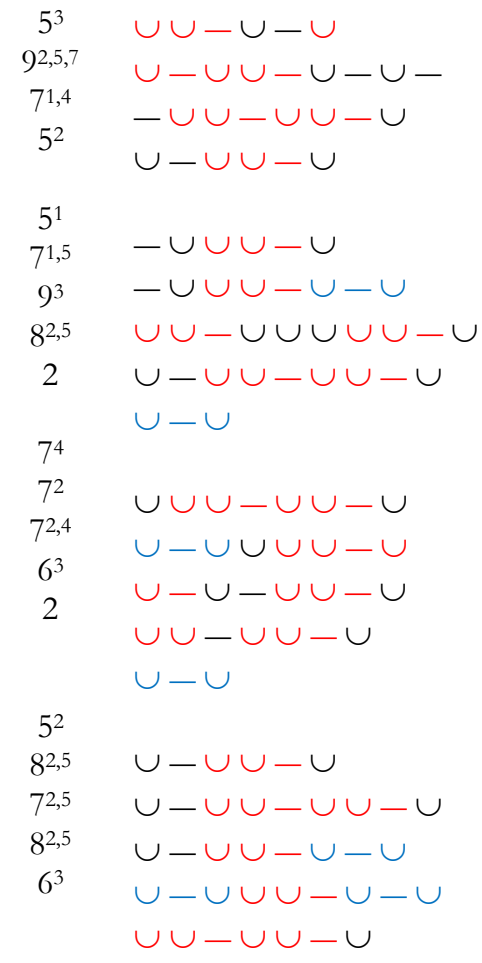

O relato da rotina de trabalho, da engrenagem burocrática que move o cotidiano e os trânsitos de sujeitos anônimos das grandes cidades, representado, sobretudo, pela homofonia entre as palavras "encargos" e "em cargos", alude à questão apresentada por esse sujeito poético nesse e nos demais poemas dos Oráculos: a desassossegada busca da compreensão das características da contemporaneidade.

\footnotetext{
10 Os grifos em itálico foram transcritos conforme a edição citada. Neste artigo, escolhi citar duas vezes cada poema analisado, pois não desejo que minha análise seja entendida como a única maneira possível de ler os poemas aqui apresentados, sendo estas algumas dentre várias outras possibilidades de leitura. Assim, em um primeiro momento, transcrevo o respectivo poema na sua inteireza e, ao seu lado, transcrevo-o, novamente, acompanhado de meus grifos. Devido a isso, desrespeitei a norma da ANBT que prevê recuo de margem de quatro centímetros à direita quando houver citação.

11 Para construir as análises dos quatro poemas deste artigo, escolhi grifar, com sublinhado, as sinalefas; com negrito as sinafias e com letras maiúsculas as sílabas tônicas finais de cada verso. A escansão dos versos e a análise dos processos de acomodação silábica foram realizadas conforme os preceitos de Chociay (1974). Utilizei os sinais “_” e " $\cup$ "para representar, respectivamente, as sílabas fortes e fracas (GOLDSTEIN, 2008, p. 14). E as células rítmicas que se repetem periodicamente, destaquei-as com o uso da cor vermelha as mais frequentes e com o uso da cor azul as menos frequentes.
} 
O movimento de narrar cenas finais de uma jornada é marcado por um ritmo ${ }^{12}$, predominantemente, anapéstico ${ }^{13}$, células rítmicas registradas na maioria dos versos com exceção dos dois versos finais das segunda e terceira estrofes em que há o uso de outra célula rítmica. As frequências de uso dos anapestos variam ao longo desse poema, pois, em um único verso, tais unidades podem estar marcadas somente uma vez; enquanto em outro, duas vezes, ou também através da união de dois segmentos silábicos finais e iniciais, respectivamente, de versos subsequentes através do uso da sinafia (Cf. CHOCIAY, 1974) (ligação entre os versos 2 e 3 da terceira estrofe). Soma-se a isso o fato de as células rítmicas anapésticas não estarem registradas em um determinado local, simetricamente, já que elas ocupam variados posicionamentos de maneira não periódica - o que poderia representar os diferentes direcionamentos percorridos pelos indivíduos nas complexas geografias da contemporaneidade - infinitas possibilidades de trânsitos.

Na perspectiva tradicional de análise, esse poema seria composto por versos livres e polimétricos, possuindo uma menor regularidade e não seguindo "nenhuma regra métrica ao apresentar, ao leitor, um ritmo novo, liberado e imprevisível" (GOLDSTEIN, 2008, p. 18). Embora haja o predomínio de anapestos, a presença de outra célula rítmica, a anfíbraca $^{14}$, é materializada no final da segunda e da terceira estrofe, como observada nos termos "nos vidros" e "enigma".

Tais versos são decisivos para construir uma leitura que vise depreender da semântica do poema o olhar do sujeito poético às rotinas do outro (segunda estrofe). Se o ritmo anapéstico for entendido como o fluxo acelerado e constante das grandes cidades ${ }^{15}$ a representação do ritmo da contemporaneidade -, os versos anfíbracos poderiam

\footnotetext{
12 Nesta seção do artigo, utilizarei o termo "ritmo" de acordo com a teoria de Calvo (2006), que reflete sobre o "ritmo aritmético" de um poema.

13 Utilizarei, ao longo do artigo, a nomenclatura das unidades rítmicas da versificação grega conforme Dain (1965). Entretanto, trabalho com a dimensão do traço "forte" e "fraco" das sílabas componentes dos versos em língua portuguesa, pois, como já pontuado por inúmeros estudiosos, a partir da versificação latina, perdeu-se a noção grega de sílabas "longas" e "breves", fundamental para a percepção do ritmo poético em textos como A Odisséia de Homero. Assim, as células rítmicas compostas por, respectivamente, três sílabas "fraca", "fraca" e "forte" $\{\{\cup-\}$, denominá-las-ei como "ritmo anapéstico".

${ }^{14}$. As células rítmicas compostas por três sílabas "fraca", "forte" e "fraca" $\cong\{\cup-\cup\}$, denominá-las-ei como "ritmo anfíbraco" (Cf. DAIN, 1965).

15 Apoio-me nas reflexões apresentadas no terceiro capítulo, "Tempo/Espaço" da Modernidade Líquida: "O tempo instantâneo e sem substância do mundo do software é também um tempo sem consequências. 'Instantaneamente' significa realização imediata, 'no ato' - mas também exaustão e desaparecimento do interesse. A distância em tempo que separa o começo do fim está diminuindo ou mesmo desaparecendo [...] As pessoas que se movem e agem com maior rapidez, que mais se aproximam do momentâneo do movimento, são as pessoas que agora mandam. [...] A dominação consiste em nossa própria capacidade de escapar, de nos desengajarmos, de estar 'em outro lugar', e no direito de decidir sobre a velocidade". (BAUMAN, 2001, p. 137 e 139).
} 
constituir-se em rupturas, não sendo casuais as suas localizações dessas células nas duas estrofes “interioranas” do poema. Assim, “o 'enigma' da vida contemporânea” desvendarse-ia através dos "vidros" de um prédio vizinho àquele sujeito observador, que, enfim, poderia se perguntar: faz sentido viver intensamente um dia após o outro em um ritmo veloz, acompanhado sempre por inúmeras obrigações, compromissos e trajetos, se, no entardecer, as "miniaturas" sempre retornam às suas casas como "meros reflexos que passam nos vidros", e para tais indivíduos "a morte não [seria] decerto / mais estranha que a vida"?

Os elementos anfíbracos evidenciam dois entrelaçamentos semânticos entre os termos "vultos" e "nos vidros", assim como acontece em "decerto", "dizer" e "morte": decerto seria proveitoso "dizer" que a "morte" da vida ocorre na banalização das rotinas do tempo contemporâneo dos "vultos" que estariam refletidos "nos vidros" da frente como imagens especulares, sendo o outro observado de maneira invertida? Duas sinafias pertencentes a essa estrofe também problematizam tais relações: a primeira, que destaca o gesto daquele que olha para o exterior de seu lar, e a última, que valoriza um suposto vínculo entre "sombra" e "enigma" da última estrofe - um enigma que assombra aquele que olha os vultos, a morte talvez refletida nos vidros das janelas vizinhas?

Consciente de a vida se esvair na passagem das horas, o sujeito poético do poema desejaria enfrentar o "enigma" sombrio ao se atentar a cada passo dado no espaço urbano, ao narrar um desassossego sentimento de angústia e ao questionar o ritmo da sociedade contemporânea sempre constante, volátil e fulgaz ao assumir uma postura diferente daquela banalizada no dia a dia ao problematizar uma das prerrogativas cruciais do seu tempo: seria "a vida" uma continuidade do ritmo urbano, o anapéstico, ou sua interrupção, o anfíbraco? Para ele, ao contrário daquelas "miniaturas", acredito que seria "a vida" uma maneira de resistir e de romper com a continuidade do impiedoso fluxo da "modernidade líquida" (BAUMAN, 2001).

Num segundo ato, leio "Are others happier" (CABRAL, 2009, p. 25) (em português, “os outros são mais felizes?”) como uma continuidade temática do poema já analisado. Entretanto, nesse, além de narrar rotinas urbanas, o sujeito poético questiona em cada "cena", o quão "feliz" seria a "livre" vida contemporânea. Eis o poema:

Quando se sentam a ler nos grandes átrios da noite entre mil luzes, jogos de água, escadas que rolam ainda
Quando se sentam a LER nos grandes átrios da NOIte entre mil luzes, jogos De Água, escadas que rolam aINda

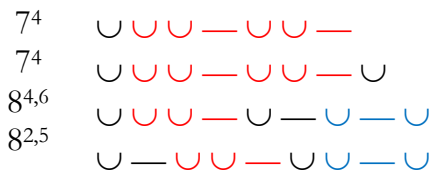


sob cúpulas de betão -

Quando saem do trabalho acossados pelo vento de meados de Fevereiro e é sempre segunda-feira nas paragens do eléctrico são mais felizes?

Quando se cruzam connosco no remanso dos jardins e encontram outro caminho de mistério, de desejo na nossa imaginação são mais felizes?

Quando os vemos mais pequenos, muito ao longe, nas esplanadas sobre o mar e por momentos nos lembram que tudo se há-de perdersão mais felizes? sob cúpulas de beTÃO são mais feLIzes?

Quando saem do traBAlho acossados pelo VENto de meados de FeveREIro e é sempre segunda-FEIra nas paragens do eLÉCtrico são mais feLIzes?

Quando se cruzam coNNOSco no remanso dos jarDINS e encontram outro caMInho de mistério, de deSEjo na nossa imaginaÇÃ O são mais feLIzes?

Quando os vemos MAIS pequenos, muito ao LONge, nas esplanadas sobre o MAR e por momentos nos LEMbram que tudo se há-de perDER são mais feLIzes?
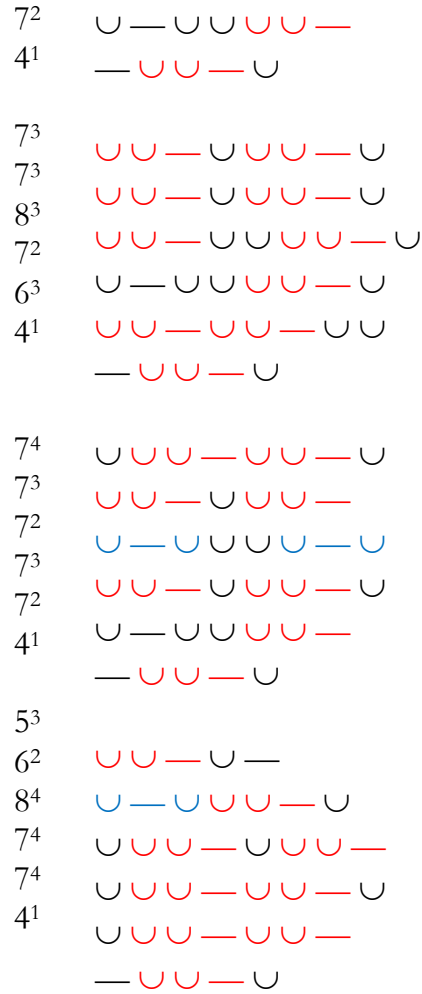

Ao considerar as presenças regulares tanto das receitas métricas, quanto das células rítmicas, é possível notar uma sonoridade quase invariável consequente de repetições de esquemas sonoros oriundos das escansões silábicas compostas, majoritariamente, por redondilhas maiores ou pelo ritmo anapéstico, registrado em maior frequência se comparado ao anfímacro. Como em "I felt that it was all unreal", busco identificar uma estabilidade sonora, registrada através da mobilização de determinada célula rítmica que se repetia ao longo do poema para que, assim, seja possível tensionar, novamente, um suposto desassossego do sujeito poético em relação à contemporaneidade, cujo ritmo seria anapéstico.

Observa-se também o uso do paralelismo, recurso formal presente nos versos finais de todas as estrofes do poema, que podem ser lidos como "ecos" originários do seu título. A presença desse recurso é sintomática para a formulação de uma leitura semelhante a do primeiro poema analisado, pois o uso do paralelismo nos versos 6, 12, 18 e 24 de "Are others happier" apaga o sujeito sintático da frase que intitula o respectivo do poema: "os outros" que foram narrados como "vultos", o que reforça a invisibilidade dos indivíduos que percorrem e habitam os centros urbanos contemporâneos.

Antes anônimos, eles passavam nos vidros da janela sob os olhares d'outrem, mas agora tais indivíduos parecem não mais serem meras "miniaturas" que atravessavam a 
cidade, pois eles são referenciados nas quatro estrofes do poema como protagonistas de cenas de uma leitura noturna da saída do trabalho e retorno às suas casa, quando eles cruzaram com o sujeito poético "no remanso dos jardins". Mais que relatar, o sujeito poético parece interagir com aqueles que antes não passavam de "vultos" e que então se tornaram "sujeitos" ao "se cruzam connosco [sic]", questão essa evidenciada pelo uso do ritmo anfímacro, como acontece no vocábulo "pequeno" da última estrofe. De "miniaturas" a "protagonistas de suas vidas", haveria a necessidade de eles se constituírem em sujeitos e de, enfim, “crescerem" frente ao olhar do outro, a partir de atitudes vivenciadas, desejadas e escolhidas.

A libertação é uma bênção ou uma maldição? Uma maldição disfarçada de bênção, ou uma bênção temida como maldição? [...] Não se engane: agora, como antes - tanto no estágio leve e fluido da modernidade quanto no sólido e pesado -, a individualização é uma fatalidade, não uma escolha. $\mathrm{Na}$ terra da liberdade individual de escolher, a opção de escapar à individualização e de se recusar a participar do jogo da individualização está decididamente fora da jogada. [...] A capacidade auto-assertiva de homens e mulheres individualizados deixa a desejar, como regra, em relação ao que a genuína autoconstituição requereria. Como observou Leo Strauss, o outro lado da liberdade ilimitada é a insignificância da escolha, cada lado condicionando o outro: por que cuidar de proibir o que será, de qualquer modo, de pouca consequência? Um observador cínico diria que a liberdade chega quando não faz mais diferença. Há um desagradável ar de impotência no temperado caldo da liberdade preparado no caldo da individualização; essa impotência é sentida como ainda mais odiosa, frustrante e perturbadora em vista do aumento de poder que se esperava que a liberdade trouxesse. Quem sabe não seria um remédio manter-se, como no passado, ombro a ombro e marchar unido? Quem sabe se, caso os poderes individuais, tão frágeis e impotentes isoladamente, fossem condensados em posições e ações coletivas, poderíamos realizar em conjunto o que ninguém poderia realizar sozinho? Quem sabe ... (BAUMAN, 2001, p. 26, 43 e 44) [...].

$\mathrm{O}$ ato de narrar tais cenas poderia configurar-se, assim, como uma forma de questionamento acerca de uma das principais características da contemporaneidade, ou da "modernidade líquida", nos termos do sociológo Zigmunt Bauman: a liberdade. Embora haja o relato de indivíduos que deixaram de ser meros "vultos" para se constituírem em sujeitos protagonistas de suas histórias, o sujeito poético parece não estar convencido de eles estarem "liberados" totalmente de uma suposta engrenagem de funcionamento da sociedade contemporânea, representada, sobretudo, pela construção de um ritmo anapéstico, o que autoriza ao narrador a questionar esse "status de liberdade de escolhas" através do registro paralelístico da interrogação "serão mais felizes?", que funciona como 
uma espécie de refrão poético, localizado sempre no verso final de cada estrofe de "Are others happier".

Seguindo a temática dos poemas analisados nos dois "atos" anteriores, "Perhaps the world's empty" (CABRAL, 2009, p. 39) (em português, “talvez o mundo esteja vazio”) problematizaria o registro poético das cenas contemporâneas, lido não só nesses, mas nos demais poemas do livro Oráculos de cabeceira. No caso desse poema, especificamente, o sujeito poético posicionar-se-ia de maneira crítica diante de seus próprios relatos ao problematizar uma suposta banalização de determinadas cenas cotidianas, como a perda e o posterior encontro de um livro:

\author{
Ninguém perde um livro \\ no comboio, ninguém o acha \\ inutilmente sublinhado \\ noutra terra, noutra cama. \\ Ninguém fuma na arcada \\ rente ao frio de Dezembro, \\ ninguém sangra no passeio \\ à mesma hora.
}

\begin{abstract}
Ninguém parte de repente à procura de mais mundo, ninguém chega por acaso ao seu nenhum sentido olhando simplesmente da varanda.
\end{abstract}

$$
\begin{aligned}
& \text { Ninguém perde um Livro } \\
& \text { no comboio, ninguém } \mathrm{O} \text { Acha } \\
& \text { inutilmente subliNHAdo } \\
& \text { noutra terra, noutra CAma. } \\
& \text { Ninguém fuma na arCAda } \\
& \text { rente ao frio de DeZEMbro, } \\
& \text { ninguém sangra no paSSEIo } \\
& \text { à mesmA HOra. }
\end{aligned}
$$
Ninguém parte de rePENte à procura de mais mUNdo, ninguém chega por aCAso ao seu nenhum senTIdo olhando simplesMENte da vaRANda.

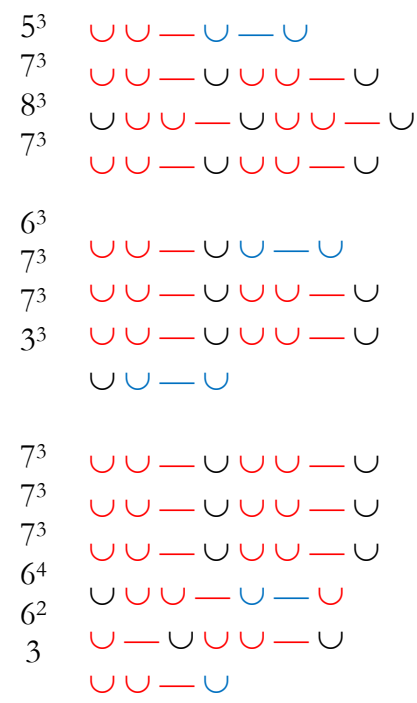

Tal postura crítica é reiterada nos versos iniciais das três estrofes do respectivo poema através do uso do vocábulo "ninguém”, duplicado nas duas primeiras e triplicado na última estrofe através da variante "nenhum". Esses vocábulos possuem valores semânticos negativos e seus registros evidenciariam um desejo de ruptura do sujeito poético que não pretenderia apenas narrar situações ocorridas nas grandes cidades sem nenhum tipo de comprometimento. Nesse seu gesto, haveria, portanto, um enfrentamento, uma tentativa de rejeitar o fluxo de acontecimento dos episódios compostos, majoritariamente, pelo uso de células rítmicas anapésticas.

Observa-se que o ritmo é estruturado também pelos elementos materializados nos dois poemas já mencionados, pois há o predomínio dos anapestos se comparados aos anfíbacros. Como já notado, o uso dessas duas células rítmicas interrompe a sensação de uma regularidade sonora, que poderia ser consequente do abusivo uso de anapestos. Entretanto, a presença de anfíbracos, aliada ao frequente uso dos vocábulos "nenhum" e 
"ninguém", reforçam, àquele que lê, um posicionamento de recusa de vivenciar o ritmo da contemporaneidade inconscientemente, pois tal postura poderia ser intensificada através da forte aliteração do fonema /n/ (além da aliteração também dos sons de vogais nasalizadas), o que reforçaria a de recusa do sujeito poético.

Da "varanda", vocábulo registrado de maneira ambígua (pode ser lido como um anapesto ou um anfíbraco), o sujeito poético assiste às cenas da contemporaneidade e as questionas, ao passo que ele reflete sobre a maneira pela qual o tempo se dilui ao longo das horas e dos dias, transcorridos num ritmo anapéstico, tensionado no mesmo momento em que as situações mais corriqueiras são narradas, como a perda de um livro ou a partida daquele "à procura de mais mundo". A velocidade da cena dá-se, porém, por um elemento pertencente à tradição portuguesa, pois, nessa viagem poética, registram-se os “eléctricos" e os "comboios", nomenclaturas de meios de transportes, utilizados há tempos em Portugal.

Encerro este artigo com a leitura do poema "Mas a cortina poderá cair agora" (CABRAL, 2009, p. 43), cujo sujeito, antes observador do fluxo da contemporaneidade, agora encenaria uma "desilusão amorosa", tema supostamente distinto daquele abordado nos outros três poemas já mencionados:

$\begin{array}{llll}\text { Um quarto } & \text { Um QUARto } & 2 & \cup-\cup \\ \text { vazio, um cobertor } & \text { vazio, um coberTOR } & 6^{2} & \cup-\cup \cup \cup- \\ \text { emprestado, um único } & \text { emprestado, um Único } & 5^{3} & \cup \cup-\cup-\cup \cup \\ \text { copo: a cenografia } & \text { copo: a cenograFIA } & 7^{1} & -\cup \cup \cup \cup \cup- \\ \text { do amor, peça } & \text { do amor, PEça } & 3 & \cup \cup \cup \cup \\ \text { em um acto. } & \text { em um ACto. } & 3 & \cup \cup \cup \cup\end{array}$

Apesar do sujeito poético não ser facilmente reconhecido, como acontece nos outros poemas dos Oráculos, materializados através do uso de pronomes, creio que ele esteja "despersonalizado" intencionalmente, pois, como já dito, sua temática contrasta com àquela observada nos demais textos. Mais do que narrar e atentar-se para as rotinas da cidade e dos trânsitos percorridos pelos seus sujeitos anônimos, há aqui o simples registro de uma cena composta por objetos: "um quarto/ vazio, um cobertor/ emprestado, um único/ copo". O relato agora é o de um espaço esvaziado de sujeito, contudo não de uma história, de um roteiro, o que pode ser lido como uma recusa do sujeito poético em continuar a observar o outro. Agora, quis ele simplesmente viver, encenar e consumar um sentimento, um gesto, o sexo. Um amor talvez despedaçado como um copo, ideia figurada pela reiteração da dupla pronuncia do seguimento fonético [ko] nos termos "único" e "copo". 
O cenário dessa cena poética compõe-se por duas células rítmicas, também notadas em "I felt that it was all unreal", "Are others happier?" e "Perhaps the world's empty": o anapesto e o anfíbraco. Entretanto, contrariamente ao que já foi apresentado neste artigo, a frequência de uso dessas células é igual e não há, nesse sentido, o predomínio de uma sobre a outra, o que pode ser lido como uma vivência, uma ruptura do sujeito poético com o fluxo da contemporaneidade, representado pelo ritmo anapéstico. $\mathrm{O}$ recurso que antes foi utilizado para demonstrar um posicionamento crítico desse sujeito - a célula rítmica anfíbraca - destaca-o, pois agora ele apenas vivenciou algo e não mais seguiu um fluxo ou desejou romper com ele. O poema constituir-se-ia, assim, como uma dramaturgia e não mais em uma narrativa, articulada por um sujeito localizado atrás dos vidros de um prédio qualquer que observa os dias passarem sem vivenciar, intensamente, os contraditórios acontecimentos da contemporaneidade, representada pelos complexos aglomerados geográficos onde os indivíduos, aparentemente, atravessavam-no sem viver ou amar. A provisoriedade dessa cena é, numericamente, mensurável, fracionária em um quarto vazio, em um cobertor emprestado, em um único copo: representações da ausência do outro, algo essencial para a composição de uma solitária cena do amor em um ato.

\section{Considerações Finais}

No presente artigo, busquei compreender o ritmo da obra de Rui Pires Cabral a partir da análise de alguns poemas dos Oráculos de cabeceira (2009). Nesse livro, nota-se a continuidade de um trabalho com temáticas relacionadas à "exploração das pequenas histórias da vida comum e no registro de uma experiência urbana de desumanização" (MARTELO, 2007, p. 49), algo já materializado em outros livros, publicados anteriormente.

Sua obra é composta por uma singular linguagem poética que usa e abusa o verso livre em praticamente todos os poemas, o que dificulta a análise de um determinado texto com base no conceito de ritmo desenvolvido pelos preceitos clássico, que dizem respeito, sobretudo, à frequência regular das sílabas ao longo do poema e à composição de versos sob a "guarda" das receitas métricas. É complicado assumir tal postura no trato com a obra de Rui Pires Cabral, pois afirmar que há a identificação de versos compostos metricamente é algo difícil, para não dizer impossível, e não creio ser essa a postura de análise mais adequada. Nesse sentido, preferi lidar de maneira "avessa" ao formular quatro análises, influenciadas pelo conceito de ritmo aritmético, de autoria do intelectual espanhol Augustín 
García Calvo para, então, estruturar minhas leituras através da observação do uso regular de células rítmicas que pudessem evidenciar algo literariamente.

Como já mencionado, há uma enorme dificuldade em conceituar ritmo, e vários foram pesquisadores, críticos e teóricos que estuda(ra)m a linguagem poética pelo viés formal e registra(ra)m o fato de haver dissonâncias teóricas em relação a tal conceito, por exemplo Amorim de Carvalho e Rogério Chociay, autores cujas obras abordei e me vali neste artigo. Acredito que definir o ritmo da obra de Rui Pires Cabral seja uma tarefa complexa, já que se trata de um conceito e não de uma definição, que varia conforme o poema a ser estudado e analisado. Mais do almejar apenas ser coerente, desejei, neste artigo, trabalhar com as noções que julgo serem as mais adequadas, funcionalmente, na leitura desses quatro poemas apresentados e da própria poesia de Rui Pires Cabral, sem perder de vista o fato de não ser suficiente a simples descrição dos fenômenos poéticos registrados em determinado texto para formular uma análise e uma proposta de leitura. $\mathrm{O}$ ritmo poético depende daquele que se propõe a ler um poema, ao passo que ele não é algo estável e fácil de ser depreendido. Nesse sentido, a noção de ritmo está atrelada também a uma das possibilidades semânticas e imagéticas, depreendida pelo leitor. Sendo assim, busquei identificar as marcas textuais, materializadas através de células rítmicas percebidas a fim de corroborar minha principal proposta de leitura: a de ser o sujeito poético de Oráculos de cabeceira um contemporâneo desassossegado com um seu tempo, que deseja romper com o fluxo dos acontecimentos ocorridos em um ritmo veloz, ágil e fulgaz, característico da modernidade líquida, e que constrói, pela palavra poética, um posicionamento crítico frente às características dessa sociedade, o que evidencia a individualização como uma escolha, uma forma de resistência, e não como uma fatalidade necessariamente.

\section{Bibliografia}

BAUDELAIRE, C. Sobre a modernidade: o pintor da vida moderna. Rio de Janeiro: Paz e Terra, 1996.

BAUMAN, Z. Modernidade Liquida. Rio de Janeiro: Zahar, 2001.

CABRAL, R. P. Longe da Aldeia. Lisboa: Averno, 2005.

Oráculos de cabeceira. Lisboa: Averno, 2009. 
CALVO, A. G. Tratado de rítmica y prosódia y de métrica y versificación. Zamora: Editorial Lucina, 2006.

CARVALHO, A. de. Teoria geral da versificação. Lisboa: Editoral Império, 1987. 2 volumes.

CHOCIAY, R. Teoria do verso. São Paulo: Editora McGraw-Hill do Brasil, 1974.

DAIN, A. Traité de métrique grecque. Paris: Editions Klincksieck, 1965.

GOLDSTEIN, N. Versos, sons, ritmos. 14 ed. São Paulo: Ática, 2008.

MAFFEI, L. Respostas imperfeitas. Disponível em: http://pequenamorte.com/2009/08/19/14-13/. Acesso em 26 set. 2011.

MARTELO, R. M. Anos noventa, breve roteiro da novíssima poesia portuguesa. Via Atlântica, São Paulo, n. 3, p. 224-237, 1999. Disponível em: http://www.fflch.usp.br/dlcv/posgraduacao/ecl/pdf/via03/via03_17.pdf. Acesso em 20 set. 2011.

Vidro do mesmo vidro: tensões e deslocamentos na poesia portuguesa depois de 1961. Porto: Campo das Letras, 2007.

MOISÉS, M. A criação literária: poesia. São Paulo: Cultrix, 2003.

VALÉRY, P. Variedades. São Paulo: Iluminuras, 1999.

Artigo recebido em 02 de Abril de 2013.

Artigo aprovado em 13 de Junho de 2013. 